\title{
Translation of the Convexity Assessment Guide into the Portuguese language
}

\author{
Tradução do Convexity Assessment Guide para a língua portuguesa \\ Traducción del Convexity Assessment Guide a la lengua portuguesa
}

\begin{abstract}
Bruna Prini Rafaldini1,2, Nádia Antônia Aparecida Poletti1,3, Paula Buck de Oliveira Ruiz', Regina Helena Squizatto ${ }^{1,5}$, Andressa de Oliveira Lopes ${ }^{1,6}$, Niara Carla de Oliveira ${ }^{1,7}$
\end{abstract}

ORCID IDS

Rafaldini BP (D) https://orcid.org/0000-0001-6086-8459

Poletti NA (D) https://orcid.org/0000-0001-9116-9773

Ruiz PBO (iD https://orcid.org/0000-0001-5598-6776

Squizatto RH (iD https://orcid.org/0000-0002-6060-1583

Lopes AO (iD https://orcid.org/0000-0002-9991-5838

de Oliveira NC (DD https://orcid.org/0000-0002-3191-6586

\section{HOW TO CITE}

Rafaldini BP, Poletti NAA, Ruiz PBO, Squizatto RH, Lopes AO, de Oliveira NC. Translation of the Convexity Assessment Guide into the Portuguese language. ESTIMA, Braz. J. Enterostomal Ther., 16: e4018. https://doi.org/10.30886/estima.v16.633 IN

\begin{abstract}
Objectives: Translate the Convexity Assessment Guide into the Portuguese language and perform its semantic, linguistic, conceptual and cultural validation. Methods: Translation study, qualitative descriptive, following the recommended phases: translation, back translation, comparison of original and translated versions back to Portuguese, validation by national experts committee. Results: It was obtained 400 evaluations - 49 annulled and 351 valid - which represents the total used for the agreement analysis of the items. After the analysis, there were six discordant items, reviewed according to the experts' suggestions, obtaining, then, a greater agreement of $90 \%$ in all items evaluated. Conclusion: There was a high level of agreement among the evaluator's committee, ensuring the continuity of the study with the cross-cultural validation of the Convexity Guide for the Brazilian reality. This research promoted the translation of an instrument that assists in the clinical indication of collector devices for stomas. The validation of the translation into the Portuguese language was obtained, being this the first phase of the process of cross-cultural validation.
\end{abstract}

DESCRIPTORS: Nursing; Stoma; Translation; Guide to Clinical Practice; Stomatherapy.

\footnotetext{
${ }^{1}$ Faculdade de Medicina de Rio Preto - Programa de Pós-Graduação em Enfermagem - São José do Rio Preto/SP - Brazil.

${ }^{2}$ Hollister do Brasil - Coordenação de Educação Clínica - São Paulo/SP - Brazil.

${ }^{3}$ Faculdade de Medicina de Rio Preto - Curso de Graduação em Enfermagem - Departamento de Enfermagem Geral - São José do Rio Preto/SP - Brazil.

${ }^{4}$ Universidade de São Paulo - Programa de Pós-Graduação em Gerenciamento em Enfermagem - São Paulo/SP - Brazil. 5Unimed São Jose do Rio Preto - Departamento de Enfermagem - Setor de Emergência - São José do Rio Preto/SP - Brazil.

${ }^{6}$ Grupo Empório Saúde - São José do Rio Preto/SP - Brazil.

7Unimed São Jose do Rio Preto - Departamento Unimed Lar - São José do Rio Preto/SP - Brazil.

Correspondence author: Bruna Prini Rafaldini | Rua São Domingos, 978/101 - Vila Caiçara | ZIP Code: 11706-380 - Praia Grande/ SP | E-mail: brunaprini@yahoo.com.br

Received: Aug 032018 | Accepted: Dec 152018
} 


\section{RESUMO}

Objetivos: Traduzir o guia Convexity Assessment Guide para a língua portuguesa e realizar sua validação semântica, linguística, conceitual e cultural. Métodos: Estudo de tradução, descritivo qualitativo, seguindo as fases preconizadas: tradução, tradução de volta à língua de origem, comparação das versões originais e da traduzida de volta ao português, validação por comitê nacional de especialistas. Resultados: Foram obtidas 400 avaliações - 49 anuladas e 351 válidas - o que representa o total utilizado para a análise de concordância dos itens. Após a análise, verificaram-se seis itens discordantes, revistos de acordo com as sugestões dos especialistas, obtendo-se, então, concordância maior de $90 \%$ em todos os itens avaliados. Conclusão: Verificou-se alto nível de concordância do comitê de avaliadores, garantindo a continuidade do estudo com a validação transcultural do Guia de Convexidade para a realidade brasileira. Esta pesquisa promoveu a tradução de instrumento que auxilia na indicação clínica de dispositivos coletores para estomias. Obteve-se a validação da tradução para a língua portuguesa, sendo essa a primeira fase do processo de validação transcultural.

DESCRITORES: Enfermagem; Estomia; Tradução; Guia de Prática Clínica; Estomaterapia.

\section{RESUMEN}

Objetivos: Traducir la guía Convexity Assessment Guide a la lengua portuguesa y realizar su validación semántica, lingüística, conceptual y cultural. Métodos: Estudio de traducción, descriptivo cualitativo, siguiendo las etapas recomendadas: traducción, traducción de vuelta a la lengua de origen, comparación de las versiones originales y de la traducida de vuelta al portugués, validación por parte de comité nacional de especialistas. Resultados: Fueron obtenidas 400 evaluaciones - 49 anuladas y 351 válidas - lo que representa el total utilizado para el análisis de concordancia de los elementos. Después del análisis, se verificaron seis elementos discordantes, revisados de acuerdo con las sugerencias de los especialistas, obteniendo, así, concordancia mayor a $90 \%$ en todos los elementos evaluados. Conclusión: Se verificó alto nivel de concordancia del comité de evaluadores, garantizando la continuidad del estudio con la validación transcultural de la Guía de Convexidad para la realidad brasileña. Esta investigación promovió la traducción de instrumento que ayuda en la indicación clínica de dispositivos colectores para estomas. Se obtuvo la validación de la traducción a la lengua portuguesa, siendo esa la primera etapa del proceso de validación transcultural.

DESCRIPTORES: Enfermería; Estoma; Traducción; Guía de Práctica Clínica; Estomaterapia.

\section{INTRODUCTION}

Currently, there is a gap in national research on the topic of translation or development of guidelines related to the use of convexity in stomas. However, this type of tool has been used efficiently in North America, as evidenced by international events such as the 2016 WOCN Society \& CAET Joint Conference, Montreal, Canada ${ }^{1}$, and in 21st WCET Biennal Congress, Cape Town, South Africa ${ }^{2}$, in which relevant studies were presented regarding the development of tools to aid in the indication of collector equipment, such as the use of convexity.

In Brazil, studies on the use of convexity and standardization of this language are still few and have been developed, for the most part, such as case studies, experience reports and bibliographic reviews only published in the summary format in annals ${ }^{3}$. Research aimed at translating instruments from different areas of care and management aims to disseminate technologies to those who have not yet benefited from the development of new diagnostics, therapeutics or tools that instrumentalize decision making. Studies such as these are widely used in health in Brazil, due to the scarcity of literature and, mainly, the complexity involved in the creation of valid national and international instruments ${ }^{4,5}$.

The lack of instruments that aid in decision making regarding the collector equipment for intestinal stomas and intestinal habits in Brazil stimulates the search for tools already scientifically proven and validated that, when translated in a judicious way and according to a methodological scope, can favor professionals and benefit the patients with a safe nursing care, based on scientific evidence ${ }^{6}$.

With the increase in the life expectancy of the Brazilian population, it was identified a growth of new stomas and longevity of those who already live with this condition, making even more critical the necessity for specialized care and the development of innovative technologies ${ }^{7}$. 
People with stomas may experience complications related to them in different periods of their lives and, despite the development of surgical techniques, complication rates still remain between 25 and $59 \%$ of patients in the first three postoperative months ${ }^{8}$.

One of the most frequently diagnosed complications is dermatitis related to the contact of the effluent with the skin, and the most used resource for the prevention of peristomal dermatitis is the use of a collector device that fits perfectly to the abdominal contours and that maintains a comfortable and safe adherence between the device and the skin. In several situations, the convexity is used to maintain this attachment of the adhesive barrier with the abdominal anatomy, allowing complete adhesion of the equipment with the skin, avoiding detachment and early leakage of the collector device?

In 2012, international researchers classified convexity as the curvature of the skin barrier that meets the peristomal skin. The terminology and convexity characteristics were classified according to depth, profile, tension, construction and flexibility. The depth may be shallow (less than $1.5 \mathrm{~mm}$ ), moderate $(1.5 \mathrm{~mm}$ to $6.3 \mathrm{~mm}$ ) and deep (above $6.3 \mathrm{~mm}$ ), depending on the slope and gradient profile, , its soft or firm flexibility, its tension that is related to low or high amont of tension and peripheral or central location. The convexity can be integrated to the barrier already in its construction or customized, according to the necessity, adding accessories, like plane rings or convex, helping in the adaptation of the equipment and preventing peristomal complications ${ }^{9}$.

The management of complications requires a multidisciplinary effort, but especially of the nurse who uses the available devices in the market; however, the evaluation guides to aid in the indication of different types of devices are scarce ${ }^{9}$. The costs involved in nursing care may be extremely high, especially in cases of peristomal complications, leading to a $75 \%$ increase in expenses ${ }^{8,10}$, values that indicate the necessity for improvements in health policies, aiming the promotion of quality reduction of losses for health services. However, these advances in the area of public and private health are materialized through scientific evidence that encourages managers with concrete and systematized data, allowing the planning and budget management conscious that allows the specialized assistance and the provision of personal collector equipment for this population group.
Some studies related to the management of complicated stomas and also the influence of medications on effluent consistency and characteristics indicate convexity in situations such as retracted stomas, skin folds, use of chemotherapy, flaccid abdomen, frequent effluent leaks or even when the durability of the equipment does not reach that expected by the user. It is these complex occurrences that have a direct impact on the lives of those living with the stoma, as well as posing great challenges for health professionals and services ${ }^{11}$.

In this context, the experience in specialized care in stomatherapy points to a lack of scientific research that supports clinical and managerial decisions. Thus, the interest for this research emerged from the absence of tools that support the decision-making of the nurse in the care of the person with the stoma and in the election of the ideal collector equipment for each patient in each moment of its life. Therefore, the translation of the Convexity Assessment Guide into the Brazilian Portuguese language becomes important as a first step towards the development of a validated instrument for the Brazilian reality, since the convexity is not yet studied in depth in Brazil.

\section{OBJECTIVES}

Translate the Convexity Assessment Guide into the Portuguese language. Perform the semantic, linguistic, conceptual and cultural validation of the Convexity Guide.

\section{METHODS}

It is a methodological study of translation, qualitative descriptive, whose methodological procedures followed were the phases announced for this methodology: translation, back-translation, comparison of the original versions and back-translation, validation of the translation by national experts committee, being realized in 2015 and 2016.

Regarding the ethical aspects, this research was the initial phase of the master's dissertation project in nursing. The use and translation of the Convexity Assessment Guide were authorized by Hollister Incorporated, Hollister of Brazil and by the main authors, who hold the instrument's patent. The participation of the nurses and translators 
was only started after completing the informed consent form. Ethical research regulations involving human subjects were respected. The study was approved by the Ethics and Research Committee ( $n^{\circ}$ 1.027.989) and the ethical precepts recommended in Resolution n ${ }^{\circ} .466$ of the National Health Council $^{12}$.

\section{Adapting the Convexity Assessment Guide to the Portuguese language}

The translation of the Convexity Assessment Guide was realized in three stages: translation, back translation and validation of the translation by the committee of experts. Only these stages were adopted because the convexity is still little studied in Brazil, requiring a greater general understanding about the theme to broaden the translation process for transcultural validation of the guide.

\section{Step 1. Translation}

The guide, in its original English version (VI1), was translated by two independent translators, originating two versions in Portuguese (VP1) and (VP2); then, were compared by three specialist nurses and fluent in the English language (E1) (two stomatherapists and a nursing master), compiling VP1 and VP2 and generating the first full version in Portuguese (VP3).

\section{Step 2. Back-translation}

VP3 was sent to two translators/teachers in English and Portuguese, not informed of the research objective, to perform the reverse translation of the guide, and VP3 was translated from Portuguese to English, generating the English version 2 (VI2) and the English version 3 (VI3).

Next, a group of four stomatherapists nurses with masters and/or doctorate in the area (E2) compared the two reverse translations (VI2 and VI3) with the original version (VI1), in order to adapt in terms of semantics, concept and Brazilian culture, thus generating the Portuguese version 4 (VP4).

\section{Step 3. Validation of the translation by the expert committee}

The VP4 was submitted as a semantic and linguistic agreement evaluation tool to a group of 10 stomatherapists nurses to verify the level of agreement with the issues described. For the study of translation, even if the methodological phase in which the group participated didn't required English language knowledge, 40\% of its participants stated that they had knowledge in basic English, 40\% intermediate and 20\% advanced. This heterogeneity of the group promotes a technical language with a range of understanding across diverse cultures and confers the national character to the validation of the instrument.

The semantic evaluation of the content refers to the analysis of the meaning of each sentence and if the sentences match the specific reality in the stomatherapy. The Likert scale ${ }^{13}$ was used with scores from 1 to 5 , in which 1 represents "strongly disagree", 2 "disagree", 3 "not agree or disagree", 4 "agree" and 5 "strongly agree" to classify semantic agreement and linguistics of the items. The acceptable level of agreement to validate each item was at least $90 \%$ among stomal therapist's opinions.

In cases in which the score represented some disagreement (score 1, 2 or 3), the nurse indicated a suggestion of change to the item. Portuguese version 5 (VP5) was the result of suggested changes and all validated items with the agreement of at least $90 \%{ }^{14}$ between the group. To check the cultural and conceptual characteristics, some items could be included or removed from the instrument.

The statistical treatment of the data was done through the program Windows Excel 2010 with analysis of the levels of agreement, using percentages based on the total of the valid answers. Exclusion criteria were used in the validation phase, such as indications of changes related to other aspects, blank responses, indications of esthetics changes and/or unrelated to semantic, linguistic, cultural and conceptual evaluation. After applying this filter, the statistical treatment had its total based only on valid data, with the nulls being subtracted from the general total. The numbers will be displayed with two decimal places and in percentage in the form of tables and figures.

\section{RESULTS}

In its original version, the introductory theoretical part was translated from English into Portuguese and submitted to the analysis of the trio of specialist nurses 
with extensive clinical experience in the area of assistance to the person with the stoma, being two stomal therapists and a master in nursing and specialist in education, all fluent in English. A degree of agreement of 100\% was obtained in the translations of the key characteristics for the evaluation of the stomas proposed by the guide (Table 1). The guide then presents the evaluation form with 40 sentences/items submitted to the three-step translation process.

The evaluation form consists of 40 phrases/evaluation items referring to the identification of the patient's profile, type of stoma, effluent characteristics, stoma, and abdominal anatomy, as well as identification of some peristomal complications. The form included fields for annotation of the concordance levels of each sentence.

The process of translation of the evaluation form from the original version VI1 to the first Portuguese language versions VP1 and VP2 did not show significant differences among the translators, is then evaluated by the trio of nurses, generating agreement above $90 \%$; thus, the VP1 and VP2 versions were consolidated in the third Portuguese version, the VP3.

There were no significant differences between the two other translators for the two Portuguese-to-English translations of the VP3 version and were analyzed by the same trio of nurses from the first stage, with a nurse doctor and specialist in skin care, being also fluent in English. The group did not identify discrepancies between translations, compiling VI2 and VI3 and validating VP3. In this phase, the quartet of specialists also realized the inclusion of the item "confection of the stoma" in the VP3, referring to the stomas in the handle or terminal stomas, an item that did not exist in VI1, in order to perform cultural and conceptual validation.
For the semantic and linguistic validation process, a group of 10 nurses was composed of nine women from different regions of Brazil, $30 \%$ of the countryside of Sao Paulo, $30 \%$ of the city of São Paulo, $20 \%$ of the state of Minas Gerais, $10 \%$ of the state of Parana and $10 \%$ of the state of Bahia. As for academic training, nine are specialists in stomatherapy and one specialist in health education, $50 \%$ masters and $20 \%$ doctors. The professionals were selected and invited to participate in the research for their professional performance, attendance to patients with stomas and knowledge on the subject, and to work in regions with large numbers of people with stomas.

With regard to familiarity, all nurses attend patients with stomas in their work routine, with $60 \%$ working in outpatient clinics specialized in stomatherapy with an average of 35 visits per week, $10 \%$ in a hospital unit specialized in stomatherapy, $30 \%$ in professional education and patients.

In the classification of the 40 items, 400 evaluations were obtained. After applying the exclusion criteria, 49 evaluations were canceled, leaving 351 valid classifications that represented the total used for the concordance analysis of each item (Figure 1).

For the classification of each item, the collector instrument followed the division of themes proposed by the original guide containing the following sessions: Patient identification; Evaluation of stoma - for terminal and/or in loop stoma; Distal stoma evaluation - only for the loop stoma; Peristomal evaluation - for all types of stomas; and Result of the evaluation. After agreement analysis of each of the 40 items, only six presented agreement less than $90 \%$ between responses, an item with $89 \%$ agreement in the Patient Identification session,

Table 1. Description of some characteristics for evaluation of the stomas according to the Convexity Assessment Guide.

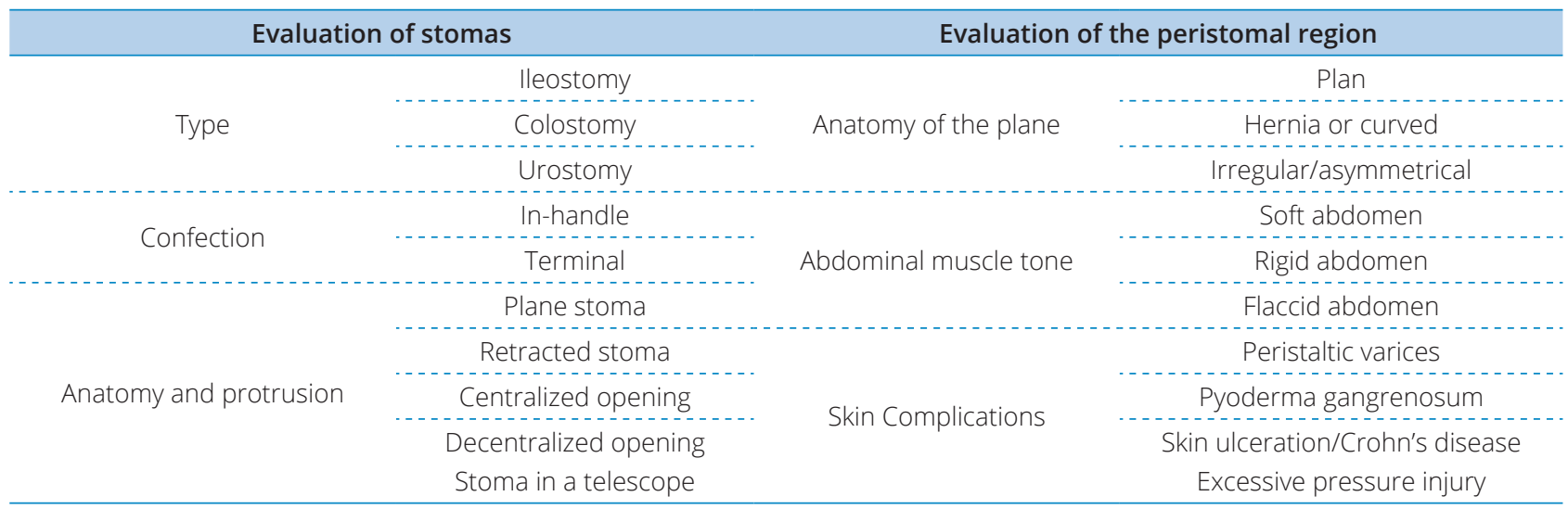




\section{DISCUSSION}

in which case one item was included by the evaluating committee, two items in the stoma assessment session - for terminal and/or in handle stoma, with 87 and $89 \%$, three items of the session Result of the evaluation presented ratings of $87 \%$ for one item and $89 \%$ for the other two (Table 2).

The items in disagreement received six suggestions for adequacy of each sentence for the Portuguese language, aiming at the technical language. These proposals were analyzed by the author and by the group of E2 nurses and, after discussion and pertinence, were realized the adjustments, reaching the levels of the agreement required for the validation of the translation.

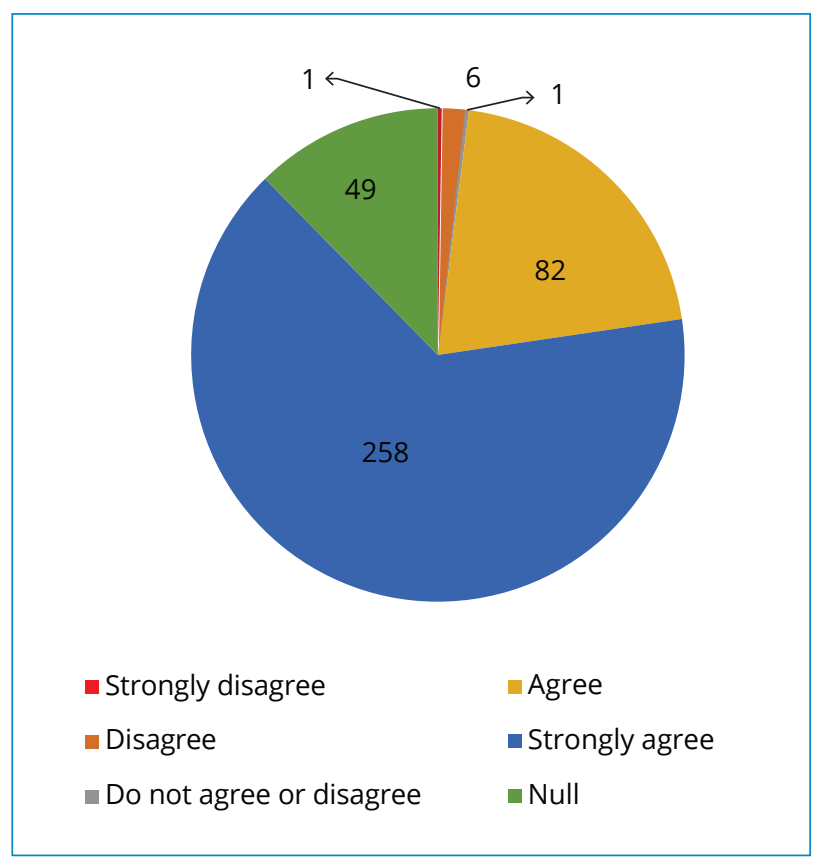

Figure 1. Graphical representation of the degrees of agreement quantification of the semantic validation instrument $(n=400)$.
The process of translation and validation of instruments for the Portuguese language has been widely used in Brazil in several sectors of the health area, due to the complexity involved in the elaboration and validation of an instrument, a situation that is complicated when it is aimed at the area of stomatherapy ${ }^{6}$. This specialty began its expansion in the 1990s, with the creation of the Brazilian Association of Stomatherapy (SOBEST), an entity that supports Brazilian stomatherapists, promoting events, courses, and the development of scientific knowledge in the $\operatorname{area}^{15}$.

The predominantly female group of stomatherapists participating in the research - 10\% (one) man and 90\% (nine) women - is in agreement with the research related to gender among nursing professionals in Brazil and, consequently, in stomatherapy, since the nurse profession is historically female ${ }^{15}$.

As to familiarity with the stoma care, the group was highly involved with technical, care and management care, since $90 \%$ work directly in the area. This characteristic is similar to that demonstrated in studies of out-of-state undergraduates in the countryside of Sao Paulo, in which $93.3 \%$ of postgraduate students already worked in the area before entering the course ${ }^{15}$. These data demonstrate the interest of this class in transforming their practical and empirical knowledge into scientific and assertive, even this behavior was also identified at all stages of this research.

The fact that there are few items in disagreement, only $17.5 \%$ of all items evaluated, shows that the language used is in accordance with the one used regularly, but disagreements represent an important point of discussion, since the specific language in stomatherapy comes still

Table 2. Presentation of the results of the validation of the items in disagreement. São Jose do Rio Preto/SP, 2017.

\begin{tabular}{|c|c|c|c|}
\hline Original version & Before validation (VP4) & Suggestions for validation & After validation \\
\hline Does not contain & Construction of the stoma & Confection of the stoma & Confection of the stoma \\
\hline $\begin{array}{l}\text { What type of output does the } \\
\text { patient have? }\end{array}$ & What kind of effluent? & What kind of effluent? & What kind of effluent? \\
\hline Where is the stoma opening? & Where is the stoma opening? & $\begin{array}{c}\text { Where is the stoma drainage } \\
\text { opening? }\end{array}$ & Where is the stoma opening? \\
\hline Assessment score indicator & Evaluation score & Evaluation result & Evaluation result \\
\hline Current products used & Current products used & Current equipments used & Current products used \\
\hline Products recommended & Products recommended & Equipments recommended & Products recommended \\
\hline
\end{tabular}

VP4 = Portuguese version 4; VP5 = Portuguese version 5. 
evolving in a timid manner, with some studies suggesting the standardization of language and systematization of pre-and-postoperative care ${ }^{4,9,16}$.

By choice of the first trio of nurses (E1), the necessity to identify, in the instrument itself, the type of preparation of the stoma, whether terminal or in the handle, was identified. Because it is a guide that should be used by specialist and non-specialist nurses, it should contain all the priority information, as added and validated by the expert committee. Even though they were among the items in disagreement, the suggestions were extremely valid and approved by the group, since a recent study confirms that several factors associated with the confection of the stoma may lead to the development of peristomal complications ${ }^{16}$.

Disagreements and discomforts related to the "effluent type" item were widely discussed, due to the importance of characterizing and measuring effluent volume, since the main complication presented by people with a stoma, peristomal dermatitis, can be caused by the direct contact of the effluent with the skin ${ }^{8}$. This type of lesion is classified as a peristomal lesion associated with moisture, by a consensus of $2013^{17}$. Just as the characterization of the effluent becomes important for the choice of the ideal equipment for the patient, the identification of the stoma opening is crucial, since its position directs the flow of the effluent can if decentralized or in a telescope, facilitate the infiltration of the effluent below the adhesive barrier of the collector bag ${ }^{18 .}$

During the validation, it was suggested by $20 \%$ of the participants that the word "score", of English origin, be replaced by "result", precisely because it is a national application guide and in the Portuguese language. Although the word "score" is widely used in Brazil, the suggestions were accepted and validated by the group ${ }^{19}$. Study of instrument translation in the orthopedic area maintained the original use of the word score only adapting to the Portuguese language "score", being evident the freedom of choice and validation of the term used for each class of professionals; in this sense, the use of the term "result", validated with $90 \%$ agreement, was accepted.

The last two items in disagreement also presented similar suggestions. Due to the similarity between the phrases, the suggestion of the expert committee was accepted, since it was the annotation and indication of several "products" related to the care of the stoma, encompassing the "equipment" collector and other accessories that help in the best adjustment to the stoma, not just the equipment ${ }^{20}$. A recent study with North American stomal therapist nurses has identified that the main product choices for the management of peristomal complications involve collector equipment with a convex base between other accessories ${ }^{21}$. These indications corroborate the choice of terminology adopted in the final version of the guide. An adequate indication of the equipment, the attendance of a stomatherapist nurse and family support are essential for the development of self-care ${ }^{22}$ since the most common peristomal skin complication is a result of effluent contact with the skin caused by the lack of adequate adjustment the type of barrier with the skin and stoma type $\mathrm{e}^{23}$. The guarantee of the health of the peristomal skin promotes quality of life to the one who lives with the stoma ${ }^{23}$.

\section{Limitations of the study}

The main limitations of the study occurred during the literature review due to the scarcity of national scientific production regarding the use of convexity in the stomas and the difficulty in recruiting stomal therapist nurses with advanced knowledge and fluency in the English language.

\section{Contributions to the nursing area}

This study promotes the first scientific evidence related to the translation of instruments that aid in the clinical indication of collector devices for elimination stomas. The validation of the translation of the Convexity Assessment Guide into the Portuguese language was obtained through this research.

\section{CONCLUSION}

In this phase of translation, semantic, linguistic, conceptual and cultural validation of the Convexity Guide, there was a high level of agreement of the evaluator's committee, ensuring continuity of the study with the cross-cultural validation of the Convexity Guide for the Brazilian reality.

This study was supported by Hollister do Brasil and Hollister Incorporated. 


\section{AUTHORS' CONTRIBUTION}

Conceptualization, Rafaldini BP and Poletti NAA; Methodology, Rafaldini BP; Poletti NA and Ruiz PBO; Investigation, Rafaldini BP; Ruiz PBO and Squizatto RH;
Writing - First version, Rafaldini BP; Writing - Review \& Editing, Rafaldini BP; Lopes AO and de Oliveira NC; Resources, Rafaldini BP; Supervision, Poletti NAA.

\section{REFERENCES}

1. Wound Ostomy and Continence Nurses Society. Scientific and Clinical Abstracts from the 2016 WOCN Society \& CAET Joint Conference; 2016 Jun 4-8; Montreal, Canada. Available at: https://journals.Iww.com/jwocnonline/pages/default.aspx

2. World Council Enterostomal Therapists. International Ostomy Guideline. [cited on 2016 Set 01]. Available at: http://www.wcetn.org/international-ostomy-guideline

3. Sociedade Brasileira de Estomaterapia. Anais do XI Congresso Brasileiro de Estomaterapia; 2015 Nov 1-4; Gramado, Brasil. Available at: http://sobest.org.br/ publicacoes/cbe-15/anais

4. Haugen $V$, Ratliff CR. Tools for assessing peristomal skin complications. J Wound Continence Nurs. 2013;40(2):131-4. https://doi.org/ 10.1097/WON.0b013e31828001a7

5. Giusti E, Befi-Lopes DM. Tradução e adaptação transcultural de instrumentos estrangeiros para o Português brasileiro (PB). Pró-Fono R Atual Científica. 2008;20(3):207-10.

6. Domansky RC, Santos VLCG. Adaptação cultural e validação do instrumento The Bowel Function in the Community para o Brasil. Rev Esc Enferm USP. 2009;43(Espec):1114-29.

7. Miranda SM, Luz MHBA, Sonobe HM, Andrade EMLR, Moura ECC. Caracterização sociodemográfica e clínica de pessoas com estoma em Teresina. ESTIMA, Braz J Enterostomal Ther. 2016;14(1):29-35. https://doi.org/10.5327/218063144201600010005

8. Salvadalena DG. The incidence of stomal and peristomal complications during the first 3 months after ostomy creation. J Wound Ostomy Continence Nurs. 2013;40(4):4006. https://doi.org/ 10.1097/WON.0b013e318295a12b

9. Hoeflok J, Kittscha J, Purnell P. Use of convexity in pouching. A comprehensive review. J Wound Continence Nurs. 2012;40(5):506-12. ht htps://doi.org/10.1097/ WON.0b013e3182a219b7

10. Nail N, Inlgese G, Manson A, Townshend A. A cost-utility model of care for periestomal skin complications. J Wound Ostomy Continence Nurs. 2016;43(1):62-8. https://doi.org/ 10.1097/WON.0000000000000194

11. Robertson JP, Wells Cl, Vather R, Bossett IP. Effect of diversion ileostomy on the occurrence and consequences of chemotherapy-induced diarrhea. Dis Colon Rectum. 2016;59(3):194-200. https://doi.org/10.1097/ DCR.0000000000000531

12. Ministério da Saúde (BR). Conselho Nacional de Saúde. Resolução No 466, de 12 de dezembro de 2012. [Internet]. Brasília, DF; 2012. Available at: http://bvsms.saude.gov.br/ bvs/saudelegis/cns/2013/res046612 12 2012.html

13. Pasquali L. Instrumentação psicológica. Fundamentos e práticas. Porto Alegre: Artmed: 2010.
14. Tilden VP, Nelson CA, May BA. Use of qualitative methods to enhance content validity. Nurs Res. 1990;39(3):172-5.

15. Dias MSC, Paula MAB, Morita ABPS. Perfil profissional de enfermeiros estomaterapeutas egressos da Universidade de Taubaté. ESTIMA, Braz J Enterostomal Ther. 2014;12(3).

16. Silva ES, Castro DS, Garcia TR, Romero WG, Primo CC. Tecnologia do cuidado à pessoa com colostomia: diagnósticos e intervenções de enfermagem. REME - Rev Min Enferm. 2016;20:e931. https://doi.org/10.5935/1415-2762.20160001

17. Gray M, Colwell JC, Doughty D, Goldberg M, HoeflikJ, Manson A et al. Peristomal moisture-associated skin damage in adults with fecal ostomies: a comprehensive review and consensus J Wound Continence Nurs. 2013;40(4):389-99. https://doi.org/10.1097/WON.0b013e3182944340

18. RatliffCR. Factors related to ostomy leakage in the community setting. J Wound Ostomy Continence Nurs. 2014;41(3):24953. https://doi.org/10.1097/WON.0000000000000017

19. Silva ALP, Croci AT, Gobbi RG, Hinckel BB, Pecora JR, Demange MK.. Tradução e validação da nova versão da escala Knee Society Score - The 2011 KS Score - para a língua portuguesa. Rev Bras Ortop. 2017;52(4):506-10. https://doi.org/10.1016/j.rbo.2016.08.005

20. Stelton S, Zulkowski K, Ayello EA. Practice implications for periestomal skin assessment and care from 2014 World Concil of Enterostomal Therapists. International Ostomy Guideline. Adv Skin Wound Care. 2015;28(6):275-84. https:// doi.org/10.1097/01.ASW.0000465374.42350.0f

21. Beitz JM, Colwel JC. Management approaches to stomal and periestomal complications. A narrative descriptive study. J Wound Continence Nurs. 2016;43(3)263-268. https://doi. org/10.1097/WON.0000000000000215

22. Luo B-J, Zheng M-C, Zhang J-E, Jiang M-X, Pan Z-Z et al. Stoma self-efficacy, hope and social relationships among patients with permanent colostomy. WCET journal. 2018;38(1):12-20.

23. Colwell JC, Pittman J, Raizman R, Salvadalena G. A randomized controlled trial determining variances in ostomy skin conditions and the economic impact (ADVOCATE Trial). J Wound Continence Nurs. 2018;45(1):37-42. https://doi.org/ 10.1097/WON.0000000000000389 